\title{
Evidence for renoxification in the tropical marine boundary layer
}

\author{
Chris Reed $^{1, a}$, Mathew J. Evans ${ }^{1,2}$, Leigh R. Crilley ${ }^{3}$, William J. Bloss ${ }^{3}$, Tomás Sherwen ${ }^{1}$, Katie A. Read ${ }^{1,2}$, \\ James D. Lee ${ }^{1,2}$, and Lucy J. Carpenter ${ }^{1}$ \\ ${ }^{1}$ Wolfson Atmospheric Chemistry Laboratories (WACL), Department of Chemistry, University of York, \\ Heslington, York, YO10 5DD, UK \\ ${ }^{2}$ National Centre for Atmospheric Science (NCAS), University of York, Heslington, York, YO10 5DD, UK \\ ${ }^{3}$ School of Geography, Earth and Environmental Sciences, University of Birmingham, Edgbaston, Birmingham, \\ B15 2TT, UK \\ ${ }^{a}$ now at: Facility for Airborne Atmospheric Measurements (FAAM), Building 146, Cranfield University, \\ Cranfield, MK43 0AL, UK
}

Correspondence to: Chris Reed (chris.paul.reed@gmail.com)

Received: 9 December 2016 - Discussion started: 9 January 2017

Revised: 7 March 2017 - Accepted: 9 March 2017 - Published: 27 March 2017

\begin{abstract}
We present 2 years of $\mathrm{NO}_{x}$ observations from the Cape Verde Atmospheric Observatory located in the tropical Atlantic boundary layer. We find that $\mathrm{NO}_{x}$ mixing ratios peak around solar noon (at 20-30 pptV depending on season), which is counter to box model simulations that show a midday minimum due to $\mathrm{OH}$ conversion of $\mathrm{NO}_{2}$ to $\mathrm{HNO}_{3}$. Production of $\mathrm{NO}_{x}$ via decomposition of organic nitrogen species and the photolysis of $\mathrm{HNO}_{3}$ appear insufficient to provide the observed noontime maximum. A rapid photolysis of nitrate aerosol to produce $\mathrm{HONO}$ and $\mathrm{NO}_{2}$, however, is able to simulate the observed diurnal cycle. This would make it the dominant source of $\mathrm{NO}_{x}$ at this remote marine boundary layer site, overturning the previous paradigm according to which the transport of organic nitrogen species, such as PAN, is the dominant source. We show that observed mixing ratios (November-December 2015) of HONO at Cape Verde ( $\sim 3.5 \mathrm{pptV}$ peak at solar noon) are consistent with this route for $\mathrm{NO}_{x}$ production. Reactions between the nitrate radical and halogen hydroxides which have been postulated in the literature appear to improve the box model simulation of $\mathrm{NO}_{x}$. This rapid conversion of aerosol phase nitrate to $\mathrm{NO}_{x}$ changes our perspective of the $\mathrm{NO}_{x}$ cycling chemistry in the tropical marine boundary layer, suggesting a more chemically complex environment than previously thought.
\end{abstract}

\section{Introduction}

The chemical environment in the remote marine boundary layer (MBL) is characterized by very low concentrations of nitrogen oxides $\left(\mathrm{NO}_{x}=\mathrm{NO}+\mathrm{NO}_{2}\right)$ i.e. 10 to $<100 \mathrm{pptV}$ (Carsey et al., 1997; Lee et al., 2009; Monks et al., 1998), high concentrations of water vapour, and the presence of inorganic halogen compounds, resulting in net daytime ozone $\left(\mathrm{O}_{3}\right)$ destruction (Dickerson et al., 1999; Read et al., 2008; Sherwen et al., 2016; Vogt et al., 1999). This MBL loss of ozone plays an important role in determining the global budget of ozone and the overall oxidizing capacity of the region. Understanding the concentrations of $\mathrm{NO}_{x}$ in these environments is thus important for determining the global ozone budget, alongside wider atmospheric chemical impacts.

$\mathrm{NO}_{x}$ in the remote MBL has been attributed to (a) longrange transport and decomposition of species such as peroxy acetyl nitrates (PAN), organic nitrates, or $\mathrm{HNO}_{3}$ (Moxim et al., 1996), (b) shipping emissions (Beirle et al., 2004), (c) a direct ocean source (Neu et al., 2008), and (d) its direct atmospheric transport (Moxim et al., 1996). However, more recently the possibility of "renoxification" by rapid nitrate photolysis on a variety of surfaces has garnered attention. Photolytic rate enhancements have been reported on aerosol nitrate (Ndour et al., 2009; Ye et al., 2016b), urban grime (Baergen and Donaldson, 2013, 2016), natural and artificial surfaces (Ye et al., 2016a), and in laboratory-prepared 
organic films and aqueous solutions (Handley et al., 2007; Scharko et al., 2014; Zhou et al., 2003).

The oxidation of $\mathrm{NO}_{2}$ to $\mathrm{HNO}_{3}$ by $\mathrm{OH}$ is the predominant sink for $\mathrm{NO}_{x}$ in the remote MBL. $\mathrm{NO}_{x}$ can also be converted into aerosol phase nitrate via the hydrolysis of $\mathrm{N}_{2} \mathrm{O}_{5}$ (Reaction R2) (Evans and Jacob, 2005), but this is a slow gas phase process in these low- $\mathrm{NO}_{x}$ environments. $\mathrm{NO}_{x}$ can be returned through $\mathrm{HNO}_{3}$ photolysis (Reaction R3) or reaction with $\mathrm{OH}$ (Reaction $\mathrm{R} 4)$, but in general these processes are again slow in the gas phase and so $\mathrm{HNO}_{3}$ can deposit to the surface, be washed out by rain, or taken up by aerosol (Reaction R5).

$$
\begin{aligned}
& \mathrm{NO}_{2}+\mathrm{OH}+\mathrm{M} \rightarrow \mathrm{HNO}_{3}+\mathrm{M} \\
& \mathrm{N}_{2} \mathrm{O}_{5}+\mathrm{H}_{2} \mathrm{O}_{(\text {aer })} \rightarrow 2 \mathrm{HNO}_{3} \text { (aer) } \\
& \mathrm{HNO}_{3}+h v \rightarrow \mathrm{OH}+\mathrm{NO}_{2} \\
& \mathrm{HNO}_{3}+\mathrm{OH} \rightarrow \mathrm{NO}_{3}+\mathrm{H}_{2} \mathrm{O} \\
& \mathrm{HNO}_{3(\mathrm{~g})}+\text { aerosol } \rightarrow \mathrm{HNO}_{3(\text { aer })}
\end{aligned}
$$

More recently the production and subsequent hydrolysis of halogen nitrates $\left(\mathrm{IONO}_{2}, \mathrm{BrONO}_{2}, \mathrm{ClONO}_{2}\right)$ have been suggested to be a potentially important sink for $\mathrm{NO}_{x}$ in the marine boundary layer (Keene et al., 2007, 2009; Lawler et al., 2009; Pszenny et al., 2004; Sander et al., 1999)

In this paper we investigate the budget of $\mathrm{NO}_{x}$ in the remote MBL using observations of $\mathrm{NO}_{x}$ and HONO collected at the Cape Verde Atmospheric Observatory during 2014 and 2015. We use a 0-D model of $\mathrm{NO}_{x}, \mathrm{HO}_{x}$, halogen, and VOC (volatile organic carbon) chemistry to interpret these observations and investigate the role that different $\mathrm{NO}_{x}$ source and sink terms play.

\section{Methodology}

The Cape Verde Atmospheric Observatory (CVO), a WMO Global Atmospheric Watch (GAW) station, is located in the tropical North Atlantic $(16.864,-24.868)$ on the island of São Vincente and is exposed to air travelling from the northeast in the trade winds (Carpenter et al., 2010). In general, the air reaching the station has travelled many days over the ocean since exposure to anthropogenic emissions; thus the station is considered representative of the remote marine boundary layer (Read et al., 2008). A large range of compounds are measured at the CVO (Carpenter et al., 2010), but we focus here on the $\mathrm{NO}$ and $\mathrm{NO}_{2}$ continuous measurements, alongside HONO measurements that were made for 10 days in winter 2015 .

\section{$2.1 \mathrm{NO}$ and $\mathrm{NO}_{2}$}

$\mathrm{NO}$ and $\mathrm{NO}_{2}$ are measured by $\mathrm{NO}$ chemiluminescence (Drummond et al., 1985) coupled to photolytic $\mathrm{NO}_{2}$ conversion by selective photolysis at $385-395 \mathrm{~nm}$ as described by
Lee et al. (2009), Pollack et al. (2011), Reed et al. (2016a, b), and Ryerson et al. (2000). A single photomultiplier detector switches between $1 \mathrm{~min}$ of chemiluminescent zero, 2 min of $\mathrm{NO}$, and 2 min of $\mathrm{NO}_{x}$ measurement.

Air is sampled from a common $40 \mathrm{~mm}$ glass manifold (QVF) which draws ambient air from a height of $10 \mathrm{~m}$ above ground level. The manifold is downward-facing into the prevailing wind at the inlet and fitted with a hood. The manifold is shielded from sunlight outside and thermostated within the lab to $30^{\circ} \mathrm{C}$ to prevent condensation. Air is drawn down by centrifugal pump at $\sim 750$ litres per minute resulting in a sample flow speed of $10 \mathrm{~m} \mathrm{~s}^{1}$ and a residence time to the $\mathrm{NO}_{x}$ instrument of $2.3 \mathrm{~s}$. Humidity and aerosol are reduced by two dead-end traps at the lowest points of the manifold inside and outside the lab, which are drained off regularly. Manifold sample flow, humidity, and temperature are recorded and logged continuously.

Air is sampled a $90^{\circ}$ to the manifold flow through $1 / 4$ inch PFA tubing at 1 standard litre per minute, being filtered through a $47 \mathrm{~mm}, 0.22 \mu \mathrm{m}$ mesh filter before entering the $\mathrm{NO}_{x}$ analyser.

The humidity of the sample gas is further reduced by a Nafion dryer (PD-50T-12-MKR, Permapure), fed by a constant sheath flow of zero air (PAG 003, Eco Physics AG), which is also filtered through a Sofnofil (Molecular Products) and activated carbon (Sigma Aldrich) trap. This reduces sample humidity variability, which affected NO sensitivity through chemiluminescent quenching (Clough and Thrush, 1967), where sample humidity can vary from 60 to $90 \%$ (Carpenter et al., 2010). Calibration for NO sensitivity and $\mathrm{NO}_{2}$ converter efficiency occurs every $73 \mathrm{~h}$ by standard addition to ambient air as described by Lee et al. (2009); in this way correction for humidity affecting sensitivity and $\mathrm{O}_{3}$ affecting $\mathrm{NO}_{2}$ conversion efficiency is unnecessary. Sensitivity drift between calibration is $<2 \%$, within the overall uncertainty of the measurement. Zero air is also used to determine the $\mathrm{NO}_{2}$ artefact signal which can arise when $\mathrm{NO}_{x}$ free air is illuminated at UV wavelengths due to the photolysis of $\mathrm{HNO}_{3}$, etc., adsorbed on the walls of the photolysis cell (Nakamura et al., 2003; Pollack et al., 2011; Ryerson et al., 2000). NO artefact correction is made by assuming that it is equivalent to a stable night-time NO value in remote regions (Lee et al., 2009), away from any emission source, where NO should be zero in the presence of $\mathrm{O}_{3}$. Reed et al. (2016b) showed that thermal interferences in $\mathrm{NO}_{2}$ using this technique may cause a bias in cold or temperate remote regions but that in warm regions, such as Cape Verde, the effect is negligible. Photolytic interferences such as $\mathrm{BrONO}_{2}$ and $\mathrm{HONO}$ and inlet effects may also alter the retrieved $\mathrm{NO}$ or $\mathrm{NO}_{2}$ (Reed et al., 2016a, b). These effects are considered to be sufficiently small that the concentrations of $\mathrm{NO}$ and $\mathrm{NO}_{2}$ can be determined within an accuracy of 5 and $5.9 \%$ respectively (Reed et al., 2016a, b) at the (very low) levels present at CVO. The instrument having a zero count rate of $\sim 1700 \mathrm{~Hz}$ with $1 \sigma$ standard deviation of that 
signal $(\sim 50 \mathrm{~Hz})$, this gives a precision of $7.2 \mathrm{pptV}$ for $1 \mathrm{~s}$ data with typical sensitivity over the measurement period of $6.9 \mathrm{cps} \mathrm{pptV}^{-1}$. The resultant limits of detection for $\mathrm{NO}$ and $\mathrm{NO}_{2}$ are 0.30 and $0.35 \mathrm{pptV}$ when averaged over $1 \mathrm{~h}$.

\subsection{HONO}

Between 24 November and 3 December 2015, a long-path absorption photometer (LOPAP) (Heland et al., 2001) was employed at CVO to provide an in situ measurement of nitrous acid. The LOPAP has its own thermostated inlet system with reactive HONO stripping to minimize losses so does not sample from the main lab manifold. The LOPAP inlet was installed on the roof of a container lab $\sim 2.5 \mathrm{~m}$ above ground level, unobstructed from the prevailing wind. Calibration and operation of the LOPAP was carried out in line with the standard procedures described by Kleffmann and Wiesen (2008). Specifically at CVO, the sampling conditions were set in order to maximize the sensitivity of the LOPAP, using a gas sampling flow rate of 2 standard litres per minute. A twopoint calibration was performed using a standard solution of nitrite $\left(\mathrm{NO}_{2}^{-}\right)$at concentrations of 0.8 and $10 \mu \mathrm{g} \mathrm{L}-1$. To account for instrument drift, baseline measurements using an overflow of high-purity $\mathrm{N}_{2}$ were performed at regular intervals $(8 \mathrm{~h})$. The detection limit of the LOPAP $(2 \sigma)$ was calculated by the variability during a typical baseline measurement under $\mathrm{N}_{2}$ and was found to be $0.2 \mathrm{pptV}$. The relative error of the LOPAP was conservatively set to $10 \%$ of the measured concentration.

\subsection{Box model}

We use the Dynamically Simple Model of Atmospheric Chemical Complexity (DSMACC) box model (Emmerson and Evans, 2009) to interpret the observed $\mathrm{NO}_{x}$ measurements. We focus on the summer season (June, July, and August) as this has the largest data coverage $(N=153)$ and is out of the dust season, which extends through winter and spring (Carpenter et al., 2010; Fomba et al., 2014; Ridley et al., 2014) and coincides with the lowest $\mathrm{NO}_{y}$ mixing ratios (Carpenter et al., 2010). The model is run for day 199 at $16.864^{\circ} \mathrm{N},-024.868^{\circ} \mathrm{W}$. We initialize the model with the mean observed $\mathrm{H}_{2} \mathrm{O}, \mathrm{CO}, \mathrm{O}_{3}$, VOCs (Carpenter et al., 2010; Read et al., 2012), and $100 \mu \mathrm{m}^{2} \mathrm{~cm}^{-3}$ aerosol surface area (Carpenter et al., 2010). We also initialize the model with $1.5 \mathrm{pptV}$ of $\mathrm{I}_{2}$ and $2.5 \mathrm{pptV}$ of $\mathrm{Br}_{2}$ to provide $\sim 1.5 \mathrm{pptV}$ of $\mathrm{IO}$ and $\sim 2.5 \mathrm{pptV} \mathrm{BrO}$ during the day, consistent with the levels measured over 9 months at the CVO during 2007 (Mahajan et al., 2010; Read et al., 2008). We use the average diurnal cycle of the measured HONO concentrations, described above. Solar radiation at this location in the tropics shows little seasonal variation, hence photolysis rates are similar in summer and autumn. This measurement period was also free of dust influence. We assume clear-sky conditions for photolysis. The meteorological parameters pressure, temper- ature, relative humidity, and boundary layer height are set to median values reported by Carpenter et al. (2010). Boundary layer height is fixed at $713 \mathrm{~m}$ as no overall seasonal or diel pattern is evident in the boundary layer height at Cape Verde (Carpenter et al., 2010). This is expected at a site representative of the marine boundary layer, which has almost no island effects (except for very rare instances of wind outside the northwesterly sector, which are excluded). Thus, we discount any influence from boundary layer height changes on the diurnal cycles presented.

The unconstrained model is run forwards in time until a stable diurnal cycle is attained, i.e. $\sim 3$ days. A full description of the model chemistry is provided in the Supplement. The base case chemistry has only gas phase sources plus gas phase and deposition sinks for $\mathrm{NO}_{x}$ as described in the Supplement.

\section{Results and discussion}

\subsection{Diurnal cycles in $\mathrm{NO}_{x}$ and HONO}

Figure 1 shows the measured mean diurnal cycles of NO, $\mathrm{NO}_{2}, \mathrm{NO}_{x}$, and $\mathrm{O}_{3}$ observed in each season (meteorological spring, summer, autumn, and winter) during 2014 and 2015. Every season shows a strong diurnal cycle in NO, peaking after solar noon at around $\sim$ 13:00 to 14:00. The diurnal cycle of $\mathrm{NO}_{2}$ is much less pronounced but also exhibits weak maxima in the early afternoon. Overall this leads to a maximum in $\mathrm{NO}_{x}$ during the day. This behaviour is consistent throughout the year and air mass, though not necessarily on a "day-to-day" basis.

The observed diurnal cycle in $\mathrm{NO}_{x}$ is hard to explain with conventional chemistry. The increase in night-time $\mathrm{NO}_{x}$ suggests a continuous source, but the maximum around noon suggests a photolytic source. Given that the predominant $\mathrm{NO}_{x}$ sink is reaction with $\mathrm{OH}$ to form $\mathrm{HNO}_{3}$, it would be expected that there would be a minimum in $\mathrm{NO}_{x}$ during the day rather than a maximum. Similar observations have been reported previously (Monks et al., 1998) at the Cape Grim Baseline Air Pollution station $(-40.683,144.670)$, a comparably remote site in the Southern Hemisphere, and during the Atlantic Stratocumulus Transition Experiment (ASTEX) cruise $\left(\sim 29^{\circ} \mathrm{N}, 24^{\circ} \mathrm{W}\right)$, which reported similar daytime $\mathrm{NO}_{x}$ production (Carsey et al., 1997). The observed behaviour in the $\mathrm{CVO} \mathrm{NO}_{x}$ was historically attributed to atmospheric thermal decomposition of $\mathrm{NO}_{y}$ species (Lee et al., 2009).

Figure 2 shows the average diurnal cycle at CVO of measured HONO concentrations. The data exhibit a strong daytime maximum peaking at noon local time (solar noon $\sim 13: 20$ ) and reaching near zero at night, indicating a photolytic source. HONO is lost through deposition, photolysis, and reaction with $\mathrm{OH}$, whilst night-time build-up is often observed (Ren et al., 2010; VandenBoer et al., 2014; Zhou et 

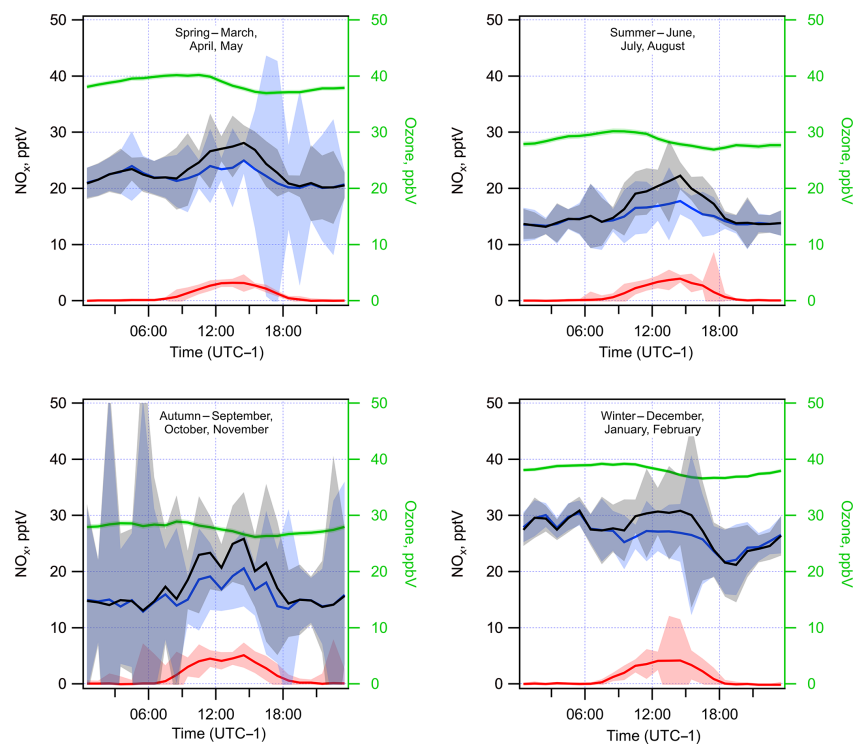

Figure 1. The observed seasonal diurnal cycles in $\mathrm{NO}, \mathrm{NO}_{2}, \mathrm{NO}_{x}$, and $\mathrm{O}_{3}$ at the CVO GAW station during 2014 and 2015. NO is shown in red, $\mathrm{NO}_{2}$ in blue, $\mathrm{NO}_{x}$ in black, and $\mathrm{O}_{3}$ in green. Shaded areas indicate the standard error of data.

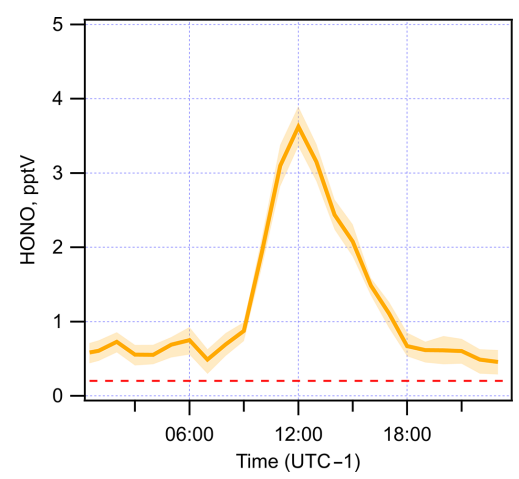

Figure 2. The observed average HONO diurnal measured at CVO during 24 November-3 December 2015. Shaded area indicates standard deviation and cumulative error of data. Dashed red line shows the HONO limit of detection.

al., 2002); here, HONO appears to reach a steady-state concentration of $\sim 0.65 \mathrm{pptV}$ throughout the night. This pseudo steady-state behaviour of nocturnal HONO has previously been reported in the polluted marine boundary layer by Wojtal et al. (2011), albeit with much higher HONO mixing ratios.

Daytime production of $\mathrm{HONO}$ is similarly hard to reconcile if its formation is by the homogeneous $\mathrm{OH}+\mathrm{NO}$ reaction (or other gas phase $\mathrm{HO}_{x}-\mathrm{NO}_{x}$ chemistry, e.g. Li et al., 2014). With NO mixing ratios below $5 \mathrm{pptV}$, OH measured peaking at $\sim 0.25 \mathrm{pptV}$ during the RHaMBLe campaign (Carpenter et al., 2010; Whalley et al., 2010), and a maximum noontime $j \mathrm{HONO}$ of $1.2 \times 10^{-3} \mathrm{~s}^{-1}$, a steady-state HONO mixing ratio of $\sim 0.04 \mathrm{pptV}$ is found
$\left(\mathrm{k}_{(\mathrm{OH}+\mathrm{NO})}=7.4 \times 10^{-12} \mathrm{~mol} \mathrm{~cm}^{-3} \mathrm{~s}^{-1}\right)$. An additional daytime source of HONO must be present to explain the observed concentrations.

Both the long-term $\mathrm{NO}_{x}$ and the short-term HONO observations made at CVO are cannot be explained with purely gas phase chemistry. Both datasets show daytime maxima indicative of a photolytic source of $\mathrm{NO}_{x}$ and HONO, whereas gas phase chemistry would predict minima in $\mathrm{NO}_{x}$ during daytime and 2 orders of magnitude less HONO.

\subsection{Box modelling of $\mathrm{NO}_{x}$ sources}

Using the box model (Sect. 2.3), we explore the observed diurnal variation in $\mathrm{NO}_{x}$ and understand the role of different processes. Classically, the predominant source of $\mathrm{NO}_{x}$ in remote regions is considered to be the thermal decomposition of compounds such as peroxyacetyl nitrate (PAN), which can be produced in regions of high $\mathrm{NO}_{x}$ and transported long distances (Fischer et al., 2014; Jacobi et al., 1999; Moxim et al., 1996). We consider a source of PAN which descends from the free troposphere and then thermally decomposes to $\mathrm{NO}_{2}$ in the warm MBL. The main sink of $\mathrm{NO}_{x}$ is conversion to $\mathrm{HNO}_{3}$, which is slightly counterbalanced by a slow conversion of $\mathrm{HNO}_{3}$ back into $\mathrm{NO}_{x}$ through gas phase photolysis or reaction with $\mathrm{OH}$. Figure 3 shows the model with a source of PAN, which results in mixing ratios of $5-8 \mathrm{pptV}$, consistent with the few measurements made in the marine boundary layer, most notably by Jacobi et al. (1999), who measured levels from $<5$ to $22 \mathrm{pptV}$ in the tropical Atlantic, and Lewis et al. (2007), who reported PAN mixing ratios of $\sim 10 \mathrm{pptV}$ in the remote mid-Atlantic MBL.

It is evident from the base case model results shown in Fig. 3 that the model fails to calculate the $\mathrm{NO}_{x}$ and $\mathrm{HONO}$ diurnal cycles. Modelled $\mathrm{NO}_{x}$ concentrations do increase during the night, consistent with the observations, but the model's minimum for $\mathrm{NO}_{x}$ occurs during the day when the observations show a maximum. The modelled and measured HONO is also shown in Fig. 3, both peaking during midday with observations reaching $3.5 \mathrm{pptV}$ whilst the model simulates only $\sim 0.2 \mathrm{pptV}$, underestimating $\mathrm{HONO}$ at all times. It is clear that long-range transport and thermal decomposition of $\mathrm{NO}_{y}$ species such as PAN alone cannot explain the $\mathrm{NO}_{x}$ diurnal at Cape Verde. A PAN-type continuous thermal decomposition forming $\mathrm{NO}_{x}$ would be inconsistent with the diurnal maximum in $\mathrm{NO}_{x}$ which is observed. The $\mathrm{NO}_{x}$ source necessary to support a noontime maximum would have to show a strong daytime maximum to counter the strong diurnal in the sink.

This need for a diurnal cycle in the $\mathrm{NO}_{x}$ source also suggests that the shipping source of $\mathrm{NO}_{x}$ is unlikely to explain the diurnal cycle. The dominant source of ship $\mathrm{NO}_{x}$ in the region is represented by the large container ships which pass the region on their way to South America or the Cape of Good Hope. It is unlikely that these emissions are system- 

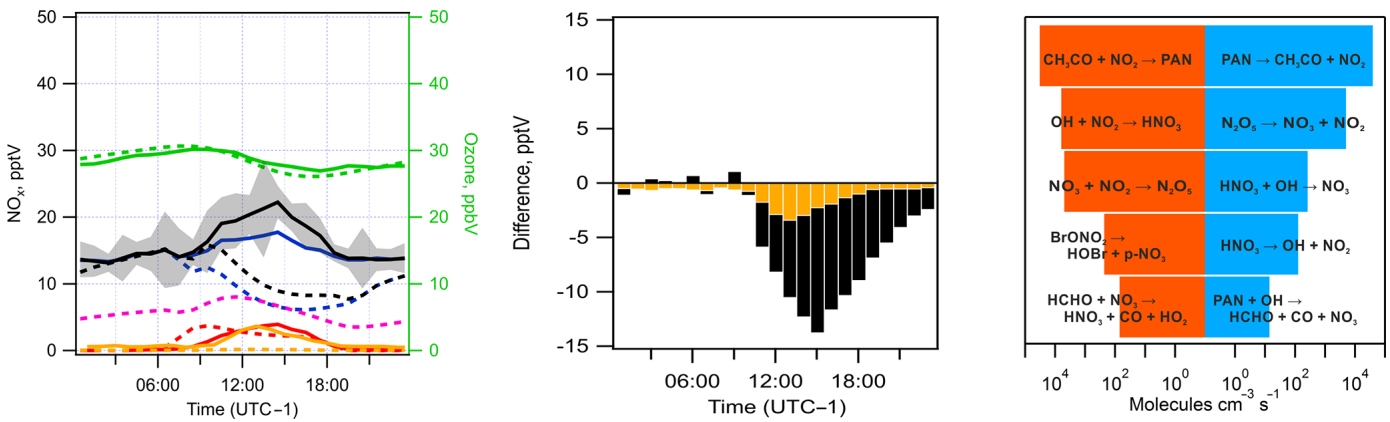

Figure 3. Left shows the measured (solid lines) and modelled (dashed) $\mathrm{NO}_{x}$ and $\mathrm{HONO}$ diurnal behaviour at the CVO GAW station where the dominant source of $\mathrm{NO}_{x}$ is a source of PAN descending from the upper troposphere having been transported from polluted regions. Shaded areas are standard error of the observations $\left(\mathrm{NO}_{x} N=153 \mathrm{HONO}, N=10\right) . \mathrm{O}_{3}-$ green; $\mathrm{NO}_{x}-$ black; $\mathrm{NO}_{2}-$ blue; $\mathrm{NO}-$ red; HONO - yellow; PAN - pink. Centre is the difference between measured and modelled $\mathrm{NO}_{x}$ (black) and HONO (yellow). Right shows the rates of production and loss of $\mathrm{NO}$ and $\mathrm{NO}_{2}$ from sources listed in descending order of contribution over a $24 \mathrm{~h}$ period accounting for $>95 \%$ of the total.

atically higher during the day than during the night, and thus they are unlikely to explain the observed diurnal signal.

There have been a number of studies which have identified much faster photolysis of nitrate within and on aerosol than for gas phase nitric acid. These include studies using real-world natural and artificial surfaces (Baergen and Donaldson, 2013; Ye et al., 2016a, b), laboratory substrates such as organic films and aqueous acid solutions (Handley et al., 2007; Scharko et al., 2014; Zhou et al., 2003), aerosol nitrate (Ndour et al., 2009; Ye et al., 2016b), and a model estimate (Cohan et al., 2008). These studies have found that particulate nitrate photolysis rates can be up to $\sim 3$ orders of magnitude greater than gas phase $\mathrm{HNO}_{3}$ photolysis in marine boundary layer conditions (Ye et al., 2016b). There is also broad agreement between different studies on the main photolysis product being nitrous acid (HONO), with $\mathrm{NO}_{2}$ as a secondary species. The product ratio appears dependent on aerosol $\mathrm{pH}$, with $\mathrm{HONO}$ production only occurring at low pH (Scharko et al., 2014). This is shown in Reaction (R6) as particulate nitrate $\left(p-\mathrm{NO}_{3}\right)$ photolysing to $\mathrm{HONO}$ and $\mathrm{NO}_{2}$ in a ratio $x: y$.

$p-\mathrm{NO}_{3}+h v \rightarrow x \mathrm{HONO}+y \mathrm{NO}_{2}$

There is also evidence that the photolysis rate is positively correlated with relative humidity (Baergen and Donaldson, 2013; Scharko et al., 2014). As such, particulate nitrate photolysis rates appear to increase with increasing aerosol acidity and relative humidity. With the CVO site experiencing relative humidity of $79 \%$ on average (Carpenter et al., 2010) and aerosol containing a significant acidic fraction (Fomba et al., 2014), particulate nitrate photolysis could have a role to play in the $\mathrm{NO}_{x}$ budget at Cape Verde.

In order to explore the implications for Cape Verde $\mathrm{NO}_{x}$ chemistry, we re-ran the base model removing the PAN source but including particulate nitrate $\left(p-\mathrm{NO}_{3}\right)$ photolysis (Reaction R6) leading to $\mathrm{HONO}$ and $\mathrm{NO}_{2}$ production, scaled

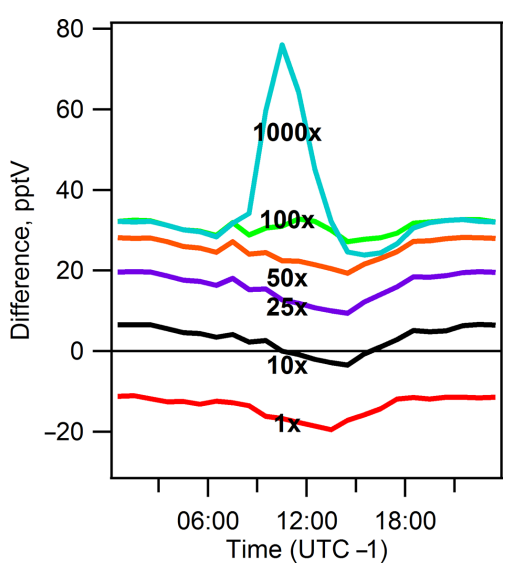

Figure 4. The difference between measured and modelled of $\mathrm{NO}_{x}$ at CVO during summer months when photolysis of nitrate is considered. The rate of particulate nitrate photolysis has been scaled to the rate of $\mathrm{HNO}_{3}$ photolysis by factors of $1,10,25,50,100$, and 1000 .

to the gas phase photolysis of $\mathrm{HNO}_{3}$. This parameterization nominally represents photolysis of nitrate within and on aerosol; however, conceptually it includes any additional surface production of $\mathrm{HONO}$ and $\mathrm{NO}_{2}$. We use an aerosol phase concentration of nitrate of $1.1 \mu \mathrm{g} \mathrm{m}^{-3}$ (equivalent to $400 \mathrm{pptV}$ ), which is the mean concentration found in $\mathrm{PM}_{10}$ aerosol at Cape Verde, with little apparent seasonal variability (Fomba et al., 2014; Savarino et al., 2013). The branching ratio of $\mathrm{HONO}$ to $\mathrm{NO}_{2}$ production from Reaction (R6) ( $x$ and $y$ ) was set to 2:1 in line with the findings of Ye et al. (2016b). We scale the $p-\mathrm{NO}_{3}$ photolysis rate to gas phase $\mathrm{HNO}_{3}$ photolysis by factors of $1,10,25,50,100$, and 1000 . The study of Ye et al. (2016b) describes enhancements of up to $\sim 300$ fold. The impact on the summer months is shown in Fig. 4. 


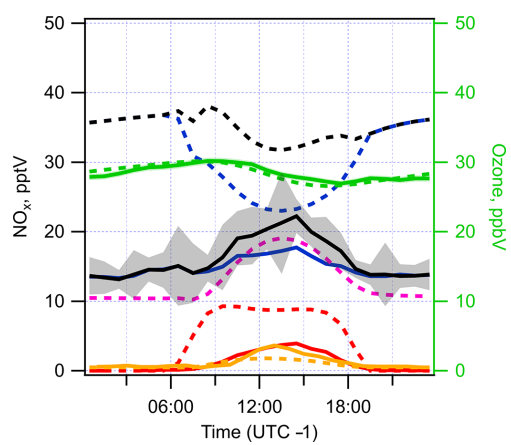

Figure 5. The modelled diurnal profile of $\mathrm{NO}_{x}$ at CVO during summer months when photolysis of nitrate (set at $10 \times$ the gas phase $\mathrm{HNO}_{3}$ photolysis) and a tropospheric PAN source are considered. Shaded areas for $\mathrm{NO}_{x}$ are the standard error of the observation. $\mathrm{O}_{3}$ - green; $\mathrm{NO}_{x}$ - black; $\mathrm{NO}_{2}$ - blue; $\mathrm{NO}$ - red; HONO - yellow; PAN - pink.

Including the photolysis of aerosol nitrate changes both the mean concentration and diurnal cycle of $\mathrm{NO}_{x}$ significantly. The diurnal $\mathrm{NO}_{x}$ is now flat or peaks during the daytime, more consistent with observations. We find that the best approximation is achieved when the rate of particulate nitrate photolysis is $\sim 10$ times that of $\mathrm{HNO}_{3}$, which is broadly consistent with laboratory-based observations (Zhou et al., 2003). A wide variability of $p-\mathrm{NO}_{3}$ photolysis rates on different surfaces is reported (Ye et al., 2016a); thus the photolysis of nitrate is uncertain and likely to be variable with aerosol composition. In all particulate nitrate photolysis-only scenarios, depicted in Figs. 4 and 5, it is evident that $p-\mathrm{NO}_{3}$ photolysis alone does not give the observed increase in nighttime $\mathrm{NO}_{x}$ observations. Conversely the PAN-only scenario is insufficient to sustain daytime $\mathrm{NO}_{x}$. It is therefore likely that the actual source of $\mathrm{NO}_{x}$ is a combination of PAN entrainment from the free troposphere and particulate nitrate photolysis.

Combining the free-tropospheric source of PAN and the photolysis of particulate nitrate at a rate of 10 times the gas phase, $\mathrm{HNO}_{3}$ photolysis (Fig. 5) results in a model simulation with roughly twice as much $\mathrm{NO}_{x}$ both at night and during daylight but a roughly flat diurnal profile. Simulated HONO peaks at local noon, similar to the observations, though the simulation underestimates the midday peak. Nocturnal HONO mixing ratios agree with observations being non-zero at $\sim 0.5 \mathrm{pptV}$.

Introduction of an additional source of $\mathrm{NO}_{x}$ is able to roughly produce a flat diurnal cycle, though it is not able to simulate a definite peak of $\mathrm{NO}_{x}$ during daytime. With the addition of a source and no change in sinks for $\mathrm{NO}_{x}$ this is unsurprising and leads to relative overestimation of $\mathrm{NO}_{x}$ particularly at night. It is therefore likely that one or more $\mathrm{NO}_{x}$ sinks are absent from the base simulation, which must be explored further.
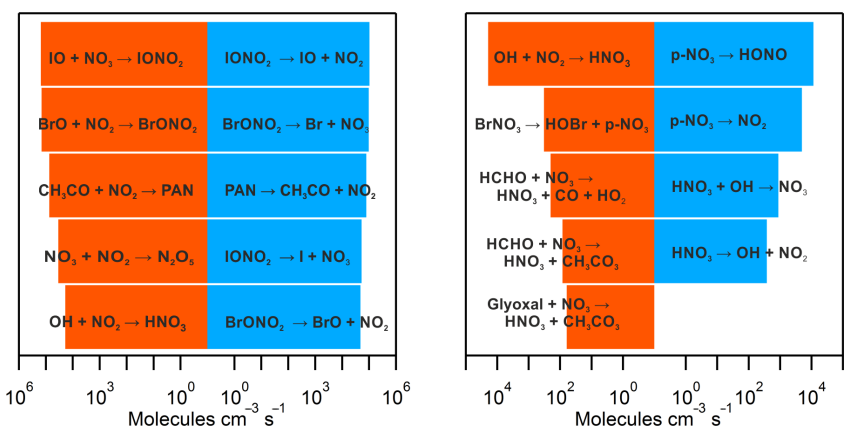

Figure 6. Left is the total production and loss analysis for $\mathrm{NO}_{x}$ of the combined model of particulate nitrate photolysis and PAN decomposition over $24 \mathrm{~h}$. Right is the same analysis discarding the major balanced sinks of fast cycling short-lived species.

\subsection{NO $\mathrm{NO}_{x}$ sinks}

Aside from loss to $\mathrm{HNO}_{3}$ directly through reaction with $\mathrm{OH}$ (Reaction $\mathrm{R} 1$ ), $\mathrm{NO}_{x}$ is also lost to nitrate by reaction with halogen oxides (XO) forming halogen nitrates (Reaction R7) (Keene et al., 2009). Read et al. (2008) showed how halogen oxides mediate ozone formation and loss at Cape Verde, thus also exerting an indirect effect on $\mathrm{NO}_{x}$.

$\mathrm{XO}+\mathrm{NO}_{2}+\mathrm{M} \rightarrow \mathrm{XONO}_{2}+\mathrm{M}$

Figure 6 shows the rates of production and loss analysis for $\mathrm{NO}_{x}$ in this simulation with both PAN thermal decomposition and particulate nitrate photolysis. The largest net source of $\mathrm{NO}_{x}$ after net sinks (such as halogen nitrate cycling) are removed is nitrate photolysis to $\mathrm{HONO}$ and $\mathrm{NO}_{2}$. The major net sink of $\mathrm{NO}_{x}$ is the formation of nitric acid by reaction of $\mathrm{NO}_{2}$ with $\mathrm{OH}$. However, uptake of $\mathrm{HNO}_{3}$ onto aerosol and subsequent rapid (compared to gas phase $\mathrm{HNO}_{3}$ ) photolysis act to balance this.

The pronounced drop in modelled $\mathrm{NO}_{2}$ at sunrise is due to the production of halogen nitrates (Reaction R7) when HOX rapidly photolyses to produce $\mathrm{XO}$, which can then react with $\mathrm{NO}_{2}$ to produce $\mathrm{XONO}_{2}$. $\mathrm{XO}$ is formed quickly and spikes in concentration, leading to the rapid loss of $\mathrm{NO}_{2}$. This feature is not observed in the $\mathrm{NO}_{x}$ observations during any season.

The diagnostics in Fig. 6 show the role of the different sinks of $\mathrm{NO}_{x}$. In that simulation these are dominated by the gas phase reaction between $\mathrm{NO}_{2}$ and $\mathrm{OH}$, but with the rapid formation and subsequent hydrolysis of $\mathrm{BrONO}_{2}$ and $\mathrm{IONO}_{2}$ (Reaction R8) playing a major role (Sander et al., 1999). The uptake coefficient $(\gamma)$ of halogen nitrates onto aerosol therefore could have a strong influence on the $\mathrm{NO}_{x}$ diurnal.

$\mathrm{XONO}_{2}+\mathrm{H}_{2} \mathrm{O}_{(\text {aer })} \rightarrow \mathrm{HNO}_{3 \text { (aer) }}+\mathrm{X}^{+}+\mathrm{OH}^{-}$

We perform a sensitivity analysis on the effect of the uptake coefficients on the $\mathrm{NO}_{x}$ and $\mathrm{XO}$ diurnals. We do this in a particulate nitrate photolysis-only simulation, without PAN, 

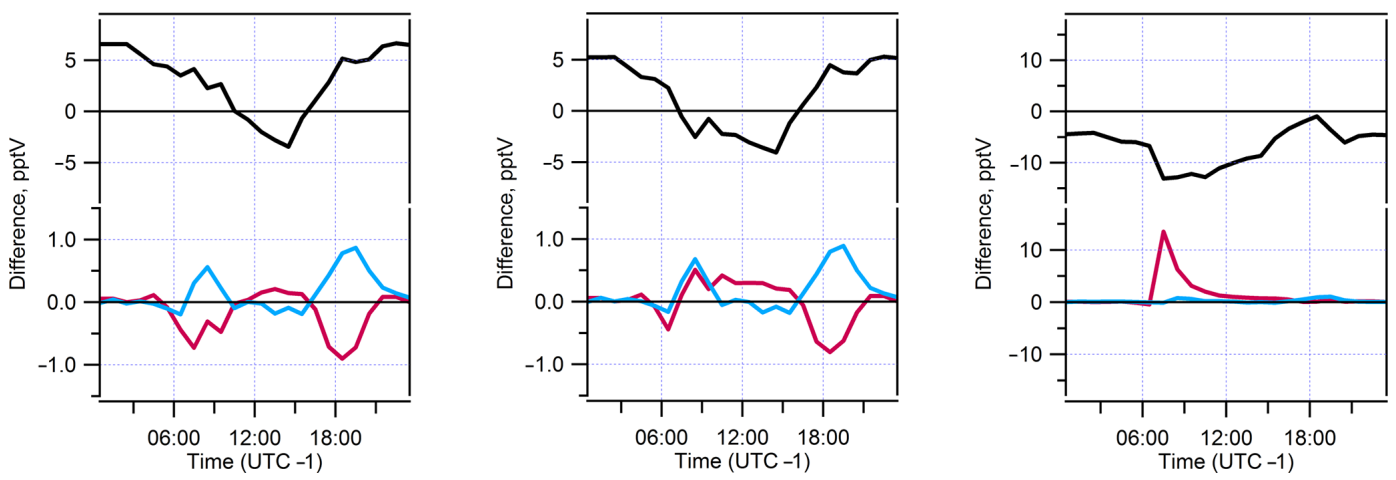

Figure 7. Sensitivity analysis of the effect of changing reactive uptake coefficients $(\gamma)$ of halogen nitrates, $\mathrm{XONO} 2(\mathrm{X}=\mathrm{Br} \mathrm{I})$, on $\mathrm{NO}_{x}$ (top), and XO (bottom) diurnal behaviour during summer months at CVO. The difference between measured and modelled values is plotted. Particulate nitrate photolysis is set at 10 times the rate of gaseous $\mathrm{HNO}_{3}$. $\mathrm{NO}_{x}$ - black; $\mathrm{IO}$ - turquoise; $\mathrm{BrO}$ - purple

to isolate the effect of $\mathrm{XONO}_{2}$ hydrolysis on nitrate $\mathrm{NO}_{x}$ cycling. Figure 7 shows the effect of changing $\gamma$ of $\mathrm{XONO}_{2}$ $(\mathrm{X}=\mathrm{Br}, \mathrm{I})$ within recommended ranges (Burkholder et al., 2015; Saiz-Lopez et al., 2008) on Saharan dust and sea salt the predominant coarse-mode aerosol by mass at Cape Verde (Carpenter et al., 2010; Fomba et al., 2014), ranging from 0.02 to 0.8 .

Increasing the $\gamma$ of $\mathrm{XONO}_{2}$ from 0.02 (the low end of recommended values) to 0.1 results in small changes to both the $\mathrm{NO}_{x}$ and $\mathrm{XO}$ diurnals. The loss of $\mathrm{NO}_{x}$ at sunrise becomes more pronounced, whereas the XO diurnals become slightly more 'square' or 'top-hat' as per the observations of Read et al. (2008). Increasing the $\gamma$ to the upper extreme $(\gamma=0.8)$ results in a spike in $\mathrm{BrO}$ at sunrise, which consumes the majority of $\mathrm{NO}_{2}$ though the formation of $\mathrm{BrONO}_{2}$. No combination of uptake coefficients can completely reproduce the characteristic XO diurnals due to poor constraints on heterogeneous halogen chemistry (Abbatt et al., 2012) in addition to gaps in the understanding of gas phase halogen chemistry (Simpson et al., 2015).

The effect on the $\mathrm{NO}_{x}$ diurnal of changing $\gamma$ is clear in that greater uptake coefficients recommended by Burkholder et al. (2015) result in objectively worse simulation of both the $\mathrm{NO}_{x}$ and $\mathrm{XO}$ diurnals. It is therefore likely that information is lacking from the $\mathrm{XO}-\mathrm{NO}_{x}$ chemistry scheme as it is currently known.

\subsection{HOI/HOBr-NO $x$ chemistry}

Recently, IO recycling by reaction with $\mathrm{NO}_{3}$ has been proposed by Saiz-Lopez et al. (2016), who calculated that the Reaction (R9) of $\mathrm{HOI}+\mathrm{NO}_{3}$ producing $\mathrm{IO}$ and $\mathrm{HNO}_{3}$ has a low enough activation energy and fast enough rate constant to be atmospherically relevant in the troposphere.

$\mathrm{HOI}+\mathrm{NO}_{3} \rightarrow \mathrm{IO}+\mathrm{HNO}_{3}: k=2.7 \times 10^{-12}(300 / T)^{2.66}$
This mechanism provides a route to nitric acid and thus particulate nitrate at night, whilst also leading to nocturnal IO production leading to loss of $\mathrm{NO}_{2}$ by $\mathrm{IONO}_{2}$ formation.

Including this new reaction and re-running the model leads to a diurnal profile of IO much more representative of the observations. This however introduces a more pronounced loss of $\mathrm{NO}_{x}$ at sunrise and sunset and also results in $\mathrm{NO}_{x}$ peaking during the day, which fits better with the observations as shown in Fig. 8. HONO is still underestimated during daytime though nocturnal values agree well.

The inclusion of this $\mathrm{HOI}+\mathrm{NO}_{3}$ reaction reproduces the general $\mathrm{NO}_{x}$ and $\mathrm{O}_{3}$ diurnals more closely than without; i.e. the model produces a daytime maximum in $\mathrm{NO}_{x}$. There are also effects on the halogen oxide behaviour. The simulated $\mathrm{BrO}$ has a flatter profile, which more closely matches the observations. However, modelled IO is now non-zero at night and the sunrise build-up and sunset decay still occurs more abruptly than the observations.

Although the $\mathrm{NO}_{x}$ and $\mathrm{O}_{3}$ diurnals are reproduced more closely with this new chemistry, there is still disagreement with the observed $\mathrm{NO}_{x}$ diurnal at sunrise and sunset especially indicating a missing reaction or reactions. To best approximate the observed diurnal behaviour an analogous $\mathrm{HOBr}+\mathrm{NO}_{3}$ night-time Reaction (R10) was introduced with a rate 10 times that of $\mathrm{HOI}+\mathrm{NO}_{3}$ as calculated by SaizLopez et al. (2016b)

$\mathrm{HOBr}+\mathrm{NO}_{3} \rightarrow \mathrm{BrO}+\mathrm{HNO}_{3}: k=2.7 \times 10^{-11}(300 / T)^{2.66}$

This results in an improved reproduction of the observed $\mathrm{NO}_{x}$ diurnal, Fig. 9. This is a purely speculative representation in order to reproduce the observed $\mathrm{NO}_{x}$ diurnal and highlights how some mechanistic knowledge of $\mathrm{NO}_{x}-$ halogen-aerosol systems is still missing.

With $\mathrm{HOX}+\mathrm{NO}_{3}$ chemistry included in the model as in Fig. 9, significant loss of $\mathrm{NO}_{x}$ at sunrise and sunset is eliminated and agreement is improved over any previous simulation. Greater HONO production is also simulated, with up to $\sim 3.0 \mathrm{pptV}$ predicted - in line with the observations 

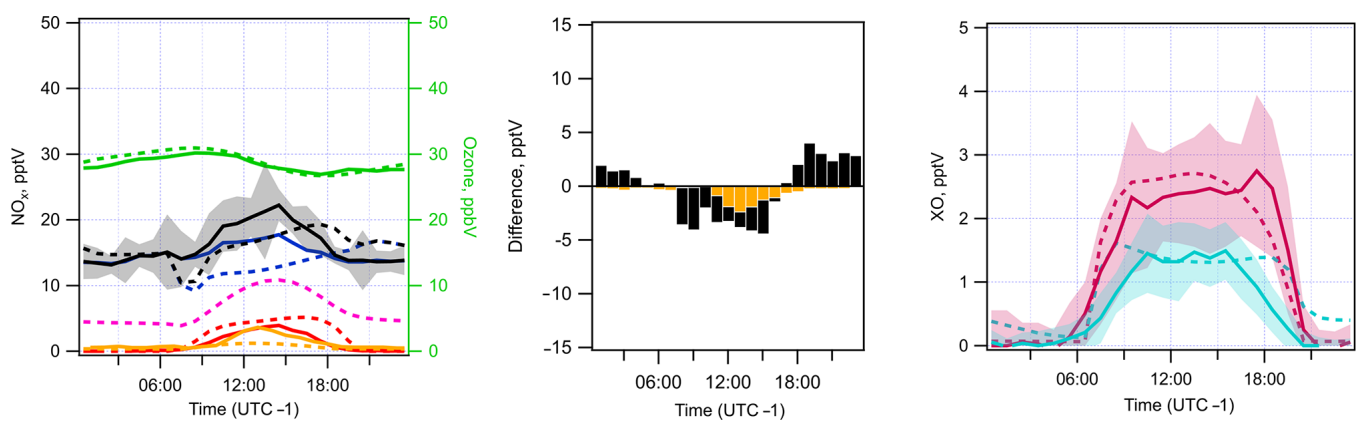

Figure 8. Left is the modelled $\mathrm{NO}_{x}$ and HONO diurnal cycle for the CVO site during summer months with the inclusion of night-time HOI chemistry. Centre shows the difference between measured and modelled values of $\mathrm{NO}_{x}$ (black) and HONO (yellow). Right is the observed (adapted from Read et al., 2008) and modelled IO and BrO. Observations are solid lines, whilst modelled values are shown dashed. Shaded areas are standard error of the observation. $\mathrm{O}_{3}$ - green; $\mathrm{NO}_{x}$ - black; $\mathrm{NO}_{2}$ - blue; $\mathrm{NO}$ - red; $\mathrm{HONO}$ - yellow; PAN - pink; IO - turquoise; $\mathrm{BrO}$ - purple.
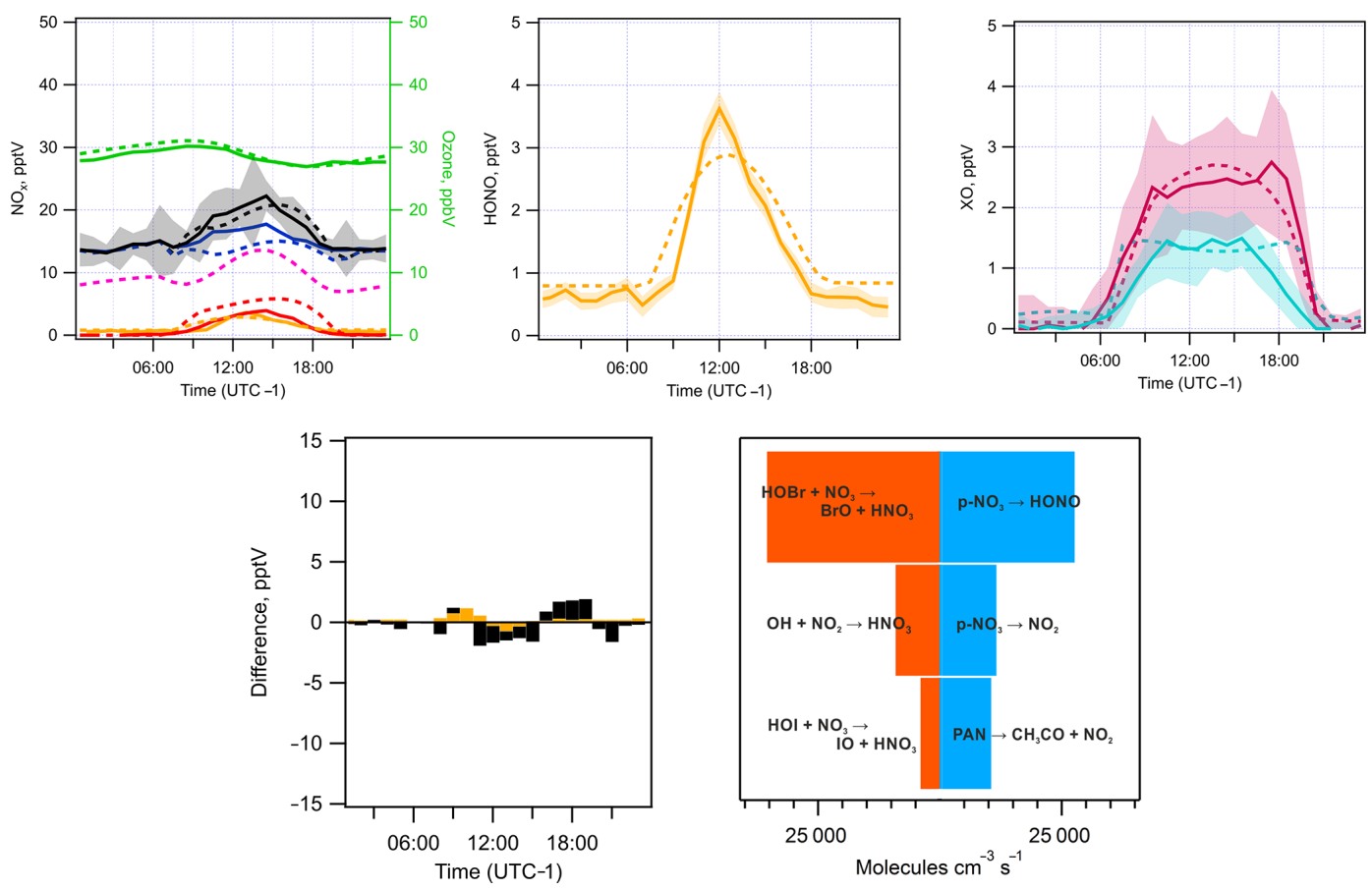

Figure 9. $\mathrm{NO}_{x}, \mathrm{O}_{3}, \mathrm{HONO}$ at $\mathrm{CVO}$ during summer months compared to model values when $\mathrm{HOI}$ and $\mathrm{HOBr}+\mathrm{NO} \mathrm{H}_{3}$ is included in the simulation. Top left: $\mathrm{NO}_{x}, \mathrm{O}_{3}, \mathrm{HONO}$, and PAN diurnal cycles. Top middle: expanded view of modelled and measured HONO. Top right: observed (adapted from Read et al., 2008) and modelled IO and $\mathrm{BrO}$. Bottom left: difference between modelled and measured $\mathrm{NO}_{x}$ and HONO. Bottom right: the net production and loss analysis for $\mathrm{NO}_{x}$ in this simulation. $\mathrm{O}_{3}-$ green; $\mathrm{NO}_{x}-$ black; $\mathrm{NO}_{2}-$ blue; $\mathrm{NO}_{-}$red; $\mathrm{HONO}$ - yellow; PAN - pink; IO - turquoise; $\mathrm{BrO}$ - purple. Measured values are solid lines, modelled values are dashed.

shown in Fig. 2. Halogen oxide modelled diurnal cycles remain broadly consistent with observations. Diagnosis of the net production and loss terms for $\mathrm{NO}_{x}$ reveal that nitrate photolysis to $\mathrm{HONO}$ or $\mathrm{NO}_{2}$ contribute $\sim 80 \%$ of all $\mathrm{NO}_{x}$, with decomposition of PAN contributing the remainder. Major net sinks of $\mathrm{NO}_{x}$ are shown to be the reaction with halogen hydroxides and $\mathrm{OH}$ to form $\mathrm{HNO}_{3}$. Nitric acid is then taken up on surfaces and recycled to $\mathrm{NO}_{x}$ through photolysis to $\mathrm{NO}_{2}$ and HONO.
The improvement can be better understood by diagnosing the modelled $\mathrm{NO}_{y}$ distribution. In Fig. 10 the distribution of PAN, $\mathrm{IONO}_{2}, \mathrm{BrONO}_{2}, \mathrm{~N}_{2} \mathrm{O}_{5}, \mathrm{NO}_{3}$, and particulate nitrate $\left(p-\mathrm{NO}_{3}\right)$ is shown for the base case scenario (where entrained PAN is the sole source of $\mathrm{NO}_{x}$ in the MBL), for the particulate nitrate photolysis case including $\mathrm{HOI}+\mathrm{NO}_{3}$ chemistry, and for the same case but including $\mathrm{HOBr}+\mathrm{NO}_{3}$ chemistry. The major feature changing through the different simulations is the magnitude and shape of the $\mathrm{BrONO}_{2}$ diur- 

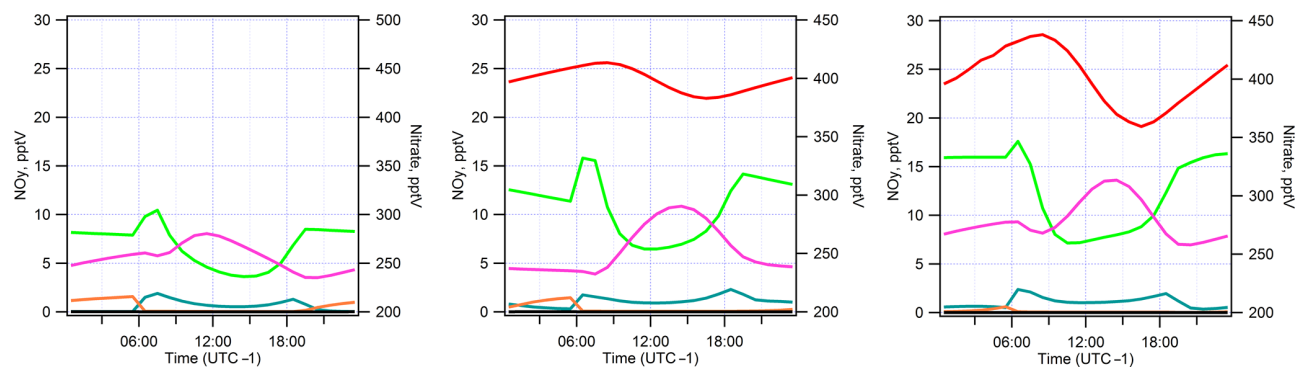

Figure 10. Shown are $\mathrm{NO}_{y}$ diurnals for the $\mathrm{CVO}$ site during summer months in the base scenario (left), with $\mathrm{HOI}+\mathrm{NO}_{3}$ chemistry included (centre), and with $\mathrm{HOI}$ and $\mathrm{HOBr}+\mathrm{NO}_{3}$ chemistry included (right). $\mathrm{BrONO}_{2}-$ green; $\mathrm{IONO}_{2}-$ teal; $\mathrm{PAN}-$ pink; $\mathrm{NO}_{3}-$ orange; $\mathrm{N}_{2} \mathrm{O}_{5}-$ black; $p-\mathrm{NO}_{3}-$ red.
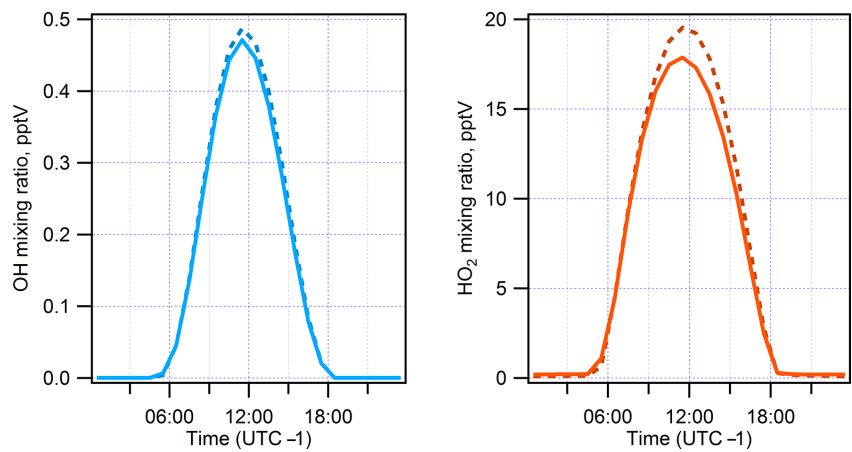

Figure 11. Modelled $\mathrm{OH}$ (left) and $\mathrm{HO}_{2}$ (right) mixing ratios comparing the base case model where PAN decomposition is the dominant source of $\mathrm{NO}_{x}$ in the remote MBL (solid lines) with the final model where the dominant source of $\mathrm{NO}_{x}$ is particulate nitrate photolysis and $\mathrm{HOX}+\mathrm{NO}_{3}$ chemistry is included (dashed lines).

nal. From the base run to the inclusion of $\mathrm{HOI}+\mathrm{NO}_{3}$ chemistry and particulate nitrate photolysis, a major increase in $\mathrm{BrONO}_{2}$ mixing ratio is expected at sunrise and sunset. It is this rapid production of $\mathrm{BrONO}_{2}$ which consumes $\mathrm{NO}_{x}$, resulting in the sharp dips at these times not seen in the observations. In the $\mathrm{HOBr}$ and $\mathrm{HOI}+\mathrm{NO}_{3}$ and particulate nitrate photolysis case these features are eliminated and halogen nitrates do not spike at sunrise or sunset. Nitrate is shown to be conserved by hydrolysis of halogen nitrates on surfaces and uptake of nitric acid. This cycling leads to an $\mathrm{NO}_{x}$ diurnal profile which is more representative of the observations.

In models which included nitrate photolysis a strong diurnal cycle in particulate nitrate presents itself which is depleted during the day and recycles at night, being conserved overall. The daily average concentration remains constant in line with the integrating filter sample study of Fomba et al. (2014).

Unsurprisingly, the inclusion of $\mathrm{HOX}+\mathrm{NO}_{3}$ chemistry results in lower mixing ratios of $\mathrm{NO}_{3}$ at night. In all cases $\mathrm{N}_{2} \mathrm{O}_{5}$ (in black) is effectively zero at all times due to very low $\mathrm{NO}_{x}$ mixing ratios in this pristine environment and the relatively high ambient temperatures $\left(24.5^{\circ} \mathrm{C}\right)$ where the
$\mathrm{N}_{2} \mathrm{O}_{5}$ lifetime is $\sim 3 \mathrm{~s}^{-1}$. This precludes $\mathrm{N}_{2} \mathrm{O}_{5}$ channels to $\mathrm{NO}_{x}$ (and ultimately nitrate), consistent with the experimental findings of Savarino et al. (2013) at Cape Verde, who found isotope ratios which were incompatible with high production rates of $\mathrm{HNO}_{3}$ from $\mathrm{N}_{2} \mathrm{O}_{5}$ hydrolysis and concluded that $\mathrm{N}_{2} \mathrm{O}_{5}$ and nitryl compound $\left(\mathrm{ClNO}_{2}, \mathrm{BrNO}_{2}\right)$ levels in this region are very low. This is consistent with our own and other studies modelling the pristine marine boundary layer at Cape Verde of Sommariva and Von Glasow (2012). This is in contrast with more polluted regions where $\mathrm{N}_{2} \mathrm{O}_{5}$ has been shown to be a route to $\mathrm{NO}_{x}$ and $\mathrm{ClNO}_{2}$ (Kim et al., 2014).

The agreement in modelled and observed $\mathrm{NO}_{x}$ improves, and the modelled values fall within the error of the observations. Additionally the approximate $\mathrm{BrO}$ diurnal is achieved without the characteristic "horns"; however, replicating IO observations is still problematic.

A dramatically changing $\mathrm{NO}_{x}$ diurnal could be expected to have an effect on $\mathrm{OH}$ and $\mathrm{HO}_{2}$ mixing ratios. The difference between the base model case, where PAN decomposition is the dominant daytime source, and the final model, where the $\mathrm{NO}_{x}$ is more accurately described by particulate nitrate photolysis and $\mathrm{HOX}+\mathrm{NO}_{3}$ chemistry, is shown in Fig. 11.

In the case of $\mathrm{OH}$ the change from the base model to the final model is an increase of $3.3 \%$ at the maximum; for $\mathrm{HO}_{2}$ the increase is a more significant $8.6 \%$ (or $1.7 \mathrm{pptV}$ ). However, this is well within the uncertainty of measured values (Whalley et al., 2010). Figure 11 shows that even with dramatic changes in the $\mathrm{NO}_{x}$ simulation, the $\mathrm{OH}$ and $\mathrm{HO}_{2}$ changes very little comparatively despite increased daytime HONO production.

From these simulations it would appear that the photolysis of surface-adsorbed nitrate may be the dominant source of $\mathrm{NO}_{x}$ in the marine boundary layer around Cape Verde. Photolysis of aerosol nitrate or nitrate in solution would be capable of producing a diurnal cycle in $\mathrm{NO}_{x}$, which was consistent with the observations when $\mathrm{HOX}+\mathrm{NO}_{3}$ chemistry is considered also. Whilst agreement between model and observation is improved, there is a clear gap in understanding the halogen- $\mathrm{NO}_{x}$-aerosol system in the remote marine boundary layer. 


\section{Conclusions}

Fast aerosol nitrate photolysis is shown to be likely the primary source of $\mathrm{NO}_{x}$ in the remote tropical Atlantic boundary layer. A 0-D model replicated the observed halogen, $\mathrm{O}_{3}$, $\mathrm{OH}, \mathrm{NO}_{x}$, and $\mathrm{HONO}$ levels when including particulate nitrate photolysis at a rate of $\sim 10$ times that of gas phase nitric acid, consistent with previous laboratory measurements. Model optimization shows that this new source of daytime $\mathrm{NO}_{2}$ is compatible with observations and currently known chemistry at night and at midday but that at sunrise and sunset there is disagreement due to the treatment of halogen oxides at these times. Recently suggested halogen hydroxide + nitrate radical chemistry may provide better agreement between model and observation if theoretical reactions can be substantiated.

Data availability. The rate and uptake coefficient data for atmospheric compounds (NASA Jet Propulsion Laboratory, Burkholder et al., 2015) are available at http://jpldataeval.jpl.nasa.gov.

All data used in this work are available from the British Atmospheric Data Centre (BADC), http://badc.nerc.ac.uk, and are included as a .csv file in the Supplement. The DSMACC model is available from https://github.com/barronh/DSMACC, and a full description of the model can be found in the Supplement.

\section{The Supplement related to this article is available online at doi:10.5194/acp-17-4081-2017-supplement.}

Competing interests. The authors declare that they have no conflict of interest.

Acknowledgements. We thank the NASA Jet Propulsion Laboratory (Burkholder et al., 2015) for providing comprehensive rate and uptake coefficient data for atmospheric compounds. The authors would like to thank Luis Neves Mendes of the Instituto Nacional de Meteorologia e Geofísica (INMG) for their operational support at the CVO site. The financial support of the National Centre for Atmospheric Science (NCAS) for the CVO measurement program and of the Natural Environmental Research Council (NERC) for the studentship of Chris Reed is gratefully acknowledged. HONO measurements were supported by NERC grant NE/M013545/1 (Sources of Nitrous Acid in the Atmospheric Boundary Layer).

Edited by: T. Bertram

Reviewed by: two anonymous referees

\section{References}

Abbatt, J. P. D., Lee, A. K. Y., and Thornton, J. A.: Quantifying trace gas uptake to tropospheric aerosol: recent advances and remaining challenges, Chem. Soc. Rev., 41, 6555, doi:10.1039/c2cs35052a, 2012.
Baergen, A. M. and Donaldson, D. J.: Photochemical renoxification of nitric acid on real urban grime, Environ. Sci. Technol., 47, 815-820, doi:10.1021/es3037862, 2013.

Baergen, A. M. and Donaldson, D. J.: Formation of reactive nitrogen oxides from urban grime photochemistry, Atmos. Chem. Phys., 16, 6355-6363, doi:10.5194/acp-16-6355-2016, 2016.

Beirle, S., Platt, U., von Glasow, R., Wenig, M., and Wagner, T.: Estimate of nitrogen oxide emissions from shipping by satellite remote sensing, Geophys. Res. Lett., 31, 4-7, doi:10.1029/2004GL020312, 2004.

Burkholder, J. B., Sander, S. P., Abbatt, J., Barker, J. R., Huie, R. E., Kolb, C. E., Kurylo, M. J., Orkin, V. L., Wilmouth, D. M., and Wine, P. H.: Chemical Kinetics and Photochemical Data for Use in Atmospheric Studies, Evaluation No. 18, JPL Publ. 15-10, 15 , http://jpldataeval.jpl.nasa.gov (last access: 10 May 2016), 2015.

Carpenter, L. J., Fleming, Z. L., Read, K. A., Lee, J. D., Moller, S. J., Hopkins, J. R., Purvis, R. M., Lewis, A. C., Müller, K., Heinold, B., Herrmann, H., Fomba, K. W., Pinxteren, D., Müller, C., Tegen, I., Wiedensohler, A., Müller, T., Niedermeier, N., Achterberg, E. P., Patey, M. D., Kozlova, E. A., Heimann, M., Heard, D. E., Plane, J. M. C., Mahajan, A., Oetjen, H., Ingham, T., Stone, D., Whalley, L. K., Evans, M. J., Pilling, M. J., Leigh, R. J., Monks, P. S., Karunaharan, A., Vaughan, S., Arnold, S. R., Tschritter, J., Pöhler, D., Frieß, U., Holla, R., Mendes, L. M., Lopez, H., Faria, B., Manning, A. J., and Wallace, D. W. R.: Seasonal characteristics of tropical marine boundary layer air measured at the Cape Verde Atmospheric Observatory, J. Atmos. Chem., 67, 87-140, doi:10.1007/s10874-011-9206-1, 2010.

Carsey, T. P., Churchill, D. D., Farmer, M. L., Fischer, C. J., Pszenny, A. A., Ross, V. B., Saltzman, E. S., Springer-Young, M., and Bonsang, B.: Nitrogen oxides and ozone production in the North Atlantic marine boundary layer, J. Geophys. Res.-Atmos., 102, 10653-10665, doi:10.1029/96JD03511, 1997.

Clough, P. N. and Thrush, B. A.: Mechanism of chemiluminescent reaction between nitric oxide and ozone, T. Faraday Soc., 63, 915, doi:10.1039/tf9676300915, 1967.

Cohan, A., Chang, W., Carreras-Sospedra, M., and Dabdub, D.: Influence of sea-salt activated chlorine and surface-mediated renoxification on the weekend effect in the South Coast Air Basin of California, Atmos. Environ., 42, 3115-3129, doi:10.1016/j.atmosenv.2007.11.046, 2008.

Dickerson, R. R., Rhoads, K. P., Carsey, T. P., Oltmans, S. J., Burrows, J. P., and Crutzen, P. J.: Ozone in the remote marine boundary layer: A possible role for halogens, J. Geophys. Res., 104, 21385-21395, doi:10.1029/1999JD900023, 1999.

Drummond, J. W., Volz, A., and Ehhalt, D. H.: An optimized chemiluminescence detector for tropospheric NO measurements, J. Atmos. Chem., 2, 287-306, doi:10.1007/BF00051078, 1985.

Emmerson, K. M. and Evans, M. J.: Comparison of tropospheric gas-phase chemistry schemes for use within global models, Atmos. Chem. Phys., 9, 1831-1845, doi:10.5194/acp-9-1831-2009, 2009.

Evans, M. J. and Jacob, D. J.: Impact of new laboratory studies of $\mathrm{N}_{2} \mathrm{O}_{5}$ hydrolysis on global model budgets of tropospheric nitrogen oxides, ozone, and OH, Geophys. Res. Lett., 32, L09813, doi:10.1029/2005GL022469, 2005.

Fischer, E. V., Jacob, D. J., Yantosca, R. M., Sulprizio, M. P., Millet, D. B., Mao, J., Paulot, F., Singh, H. B., Roiger, A., Ries, L., Talbot, R. W., Dzepina, K., and Pandey Deolal, S.: Atmospheric 
peroxyacetyl nitrate (PAN): a global budget and source attribution, Atmos. Chem. Phys., 14, 2679-2698, doi:10.5194/acp-142679-2014, 2014.

Fomba, K. W., Müller, K., van Pinxteren, D., Poulain, L., van Pinxteren, M., and Herrmann, H.: Long-term chemical characterization of tropical and marine aerosols at the Cape Verde Atmospheric Observatory (CVAO) from 2007 to 2011, Atmos. Chem. Phys., 14, 8883-8904, doi:10.5194/acp-14-8883-2014, 2014.

Handley, S. R., Clifford, D., and Donaldson, D. J.: Photochemical Loss of Nitric Acid on Organic Films: a Possible Recycling Mechanism for $\mathrm{NO}_{x}$, Environ. Sci. Technol., 41, 3898-3903, doi:10.1021/es062044z, 2007.

Heland, J., Kleffmann, J., Kurtenbach, R., and Wiesen, P.: A new instrument to measure gaseous nitrous acid (HONO) in the atmosphere, Environ. Sci. Technol., 35, 3207-3212, doi:10.1021/es000303t, 2001.

Jacobi, H.-W.-W., Weller, R., Bluszcz, T., and Schrems, O.: Latitudinal distribution of peroxyacetyl nitrate (PAN) over the Atlantic Ocean, J. Geophys. Res., 104, 26901-26912, doi:10.1029/1999JD900462, 1999.

Keene, W. C., Stutz, J., Pszenny, A. A. P., Maben, J. R., Fischer, E. V., Smith, A. M., von Glasow, R., Pechtl, S., Sive, B. C., and Varner, R. K.: Inorganic chlorine and bromine in coastal New England air during summer, J. Geophys. Res., 112, D10S12, doi:10.1029/2006JD007689, 2007.

Keene, W. C., Long, M. S., Pszenny, A. A. P., Sander, R., Maben, J. R., Wall, A. J., O’Halloran, T. L., Kerkweg, A., Fischer, E. V., and Schrems, O.: Latitudinal variation in the multiphase chemical processing of inorganic halogens and related species over the eastern North and South Atlantic Oceans, Atmos. Chem. Phys., 9, 7361-7385, doi:10.5194/acp-9-7361-2009, 2009.

Kim, M. J., Farmer, D. K., and Bertram, T. H.: A controlling role for the air-sea interface in the chemical processing of reactive nitrogen in the coastal marine boundary layer, P. Natl. Acad. Sci. USA, 111, 1-6, doi:10.1073/pnas.1318694111, 2014.

Kleffmann, J. and Wiesen, P.: Technical Note: Quantification of interferences of wet chemical HONO LOPAP measurements under simulated polar conditions, Atmos. Chem. Phys., 8, 6813-6822, doi:10.5194/acp-8-6813-2008, 2008.

Lawler, M. J., Finley, B. D., Keene, W. C., Pszenny, A. A. P., Read, K. A., Von Glasow, R., and Saltzman, E. S.: Pollutionenhanced reactive chlorine chemistry in the eastern tropical Atlantic boundary layer, Geophys. Res. Lett., 36, 3-7, doi:10.1029/2008GL036666, 2009.

Lee, J. D., Moller, S. J., Read, K. A., Lewis, A. C., Mendes, L., and Carpenter, L. J.: Year-round measurements of nitrogen oxides and ozone in the tropical North Atlantic marine boundary layer, J. Geophys. Res., 114, D21302, doi:10.1029/2009JD011878, 2009.

Lewis, A. C., Evans, M. J., Methven, J., Watson, N., Lee, J. D., Hopkins, J. R., Purvis, R. M., Arnold, S. R., McQuaid, J. B., Whalley, L. K., Pilling, M. J., Heard, D. E., Monks, P. S., Parker, A. E., Reeves, C. E., Oram, D. E., Mills, G., Bandy, B. J., Stewart, D., Coe, H., Williams, P., and Crosier, J.: Chemical composition observed over the mid-Atlantic and the detection of pollution signatures far from source regions, J. Geophys. Res., 112, D10S39, doi:10.1029/2006JD007584, 2007.

Li, X., Rohrer, F., Hofzumahaus, A., Brauers, T., Haseler, R., Bohn, B., Broch, S., Fuchs, H., Gomm, S., Holland, F., Jager, J., Kaiser, J., Keutsch, F. N., Lohse, I., Lu, K., Tillmann, R., Wegener, R.,
Wolfe, G. M., Mentel, T. F., Kiendler-Scharr, A., and Wahner, A.: Missing Gas-Phase Source of HONO Inferred from Zeppelin Measurements in the Troposphere, Science, 344, 292-296, doi:10.1126/science.1248999, 2014.

Mahajan, A. S., Plane, J. M. C., Oetjen, H., Mendes, L., Saunders, R. W., Saiz-Lopez, A., Jones, C. E., Carpenter, L. J., and McFiggans, G. B.: Measurement and modelling of tropospheric reactive halogen species over the tropical Atlantic Ocean, Atmos. Chem. Phys., 10, 4611-4624, doi:10.5194/acp-10-4611-2010, 2010.

Monks, P. S., Carpenter, L. J., Penkett, S. A., Ayers, G. P., Gillett, R. W., Galbally, I. E., and Meyer, C. P.: Fundamental ozone photochemistry in the remote marine boundary layer: The SOAPEX experiment, measurement and theory, Atmos. Environ., 32, 3647-3664, doi:10.1016/S1352-2310(98)00084-3, 1998.

Moxim, W. J., Levy, H., and Kasibhatla, P. S.: Simulated global tropospheric PAN: Its transport and impact on $\mathrm{NO}_{x}, \mathrm{~J}$. Geophys. Res.-Atmos., 101, 12621-12638, doi:10.1029/96JD00338, 1996.

Nakamura, K., Kondo, Y., Chen, G., Crawford, J. H., Takegawa, N., Koike, M., Kita, K., Miyazaki, Y., Shetter, R. E., Lefer, B. L., Avery, M., and Matsumoto, J.: Measurement of $\mathrm{NO}_{2}$ by the photolysis conversion technique during the Transport and Chemical Evolution Over the Pacific (TRACE-P) campaign, J. Geophys. Res.Atmos., 108, ACH 1-ACH 11, doi:10.1029/2003JD003712, 2003.

Ndour, M., Conchon, P., D’Anna, B., Ka, O., and George, C.: Photochemistry of mineral dust surface as a potential atmospheric renoxification process, Geophys. Res. Lett., 36, L05816, doi:10.1029/2008GL036662, 2009.

Neu, J. L., Lawler, M. J., Prather, M. J., and Saltzman, E. S.: Oceanic alkyl nitrates as a natural source of tropospheric ozone, Geophys. Res. Lett., 35, L13814, doi:10.1029/2008GL034189, 2008.

Pollack, I. B., Lerner, B. M., and Ryerson, T. B.: Evaluation of ultraviolet light-emitting diodes for detection of atmospheric $\mathrm{NO}_{2}$ by photolysis - chemiluminescence, J. Atmos. Chem., 65, 111-125, doi:10.1007/s10874-011-9184-3, 2011.

Pszenny, A. A. P., Moldanová, J., Keene, W. C., Sander, R., Maben, J. R., Martinez, M., Crutzen, P. J., Perner, D., and Prinn, R. G.: Halogen cycling and aerosol $\mathrm{pH}$ in the Hawaiian marine boundary layer, Atmos. Chem. Phys., 4, 147-168, doi:10.5194/acp-4147-2004, 2004.

Read, K. A., Mahajan, A. S., Carpenter, L. J., Evans, M. J., Faria, B. V. E., Heard, D. E., Hopkins, J. R., Lee, J. D., Moller, S. J., Lewis, A. C., Mendes, L., McQuaid, J. B., Oetjen, H., Saiz-Lopez, A., Pilling, M. J., and Plane, J. M. C.: Extensive halogen-mediated ozone destruction over the tropical Atlantic Ocean, Nature, 453, 1232-1235, doi:10.1038/nature07035, 2008.

Read, K. A., Carpenter, L. J., Arnold, S. R., Beale, R., Nightingale, P. D., Hopkins, J. R., Lewis, A. C., Lee, J. D., Mendes, L., and Pickering, S. J.: Multiannual observations of acetone, methanol, and acetaldehyde in remote tropical atlantic air: implications for atmospheric OVOC budgets and oxidative capacity., Environ. Sci. Technol., 46, 11028-11039, doi:10.1021/es302082p, 2012.

Reed, C., Brumby, C. A., Crilley, L. R., Kramer, L. J., Bloss, W. J., Seakins, P. W., Lee, J. D., and Carpenter, L. J.: HONO measurement by differential photolysis, Atmos. Meas. Tech., 9, 2483 2495, doi:10.5194/amt-9-2483-2016, 2016a. 
Reed, C., Evans, M. J., Di Carlo, P., Lee, J. D., and Carpenter, L. J.: Interferences in photolytic $\mathrm{NO}_{2}$ measurements: explanation for an apparent missing oxidant?, Atmos. Chem. Phys., 16, 47074724, doi:10.5194/acp-16-4707-2016, 2016 b.

Ren, X., Gao, H., Zhou, X., Crounse, J. D., Wennberg, P. O., Browne, E. C., LaFranchi, B. W., Cohen, R. C., McKay, M., Goldstein, A. H., and Mao, J.: Measurement of atmospheric nitrous acid at Bodgett Forest during BEARPEX2007, Atmos. Chem. Phys., 10, 6283-6294, doi:10.5194/acp-10-6283-2010, 2010.

Ridley, D. A., Heald, C. L., and Prospero, J. M.: What controls the recent changes in African mineral dust aerosol across the Atlantic?, Atmos. Chem. Phys., 14, 5735-5747, doi:10.5194/acp14-5735-2014, 2014.

Ryerson, T. B., Williams, E. J., and Fehsenfeld, F. C.: An efficient photolysis system for fast-response $\mathrm{NO}_{2}$ measurements, $\mathrm{J}$. Geophys. Res., 105, 26447-26461, doi:10.1029/2000JD900389, 2000.

Saiz-Lopez, A., Plane, J. M. C., Mahajan, A. S., Anderson, P. S., Bauguitte, S. J.-B., Jones, A. E., Roscoe, H. K., Salmon, R. A., Bloss, W. J., Lee, J. D., and Heard, D. E.: On the vertical distribution of boundary layer halogens over coastal Antarctica: implications for $\mathrm{O}_{3}, \mathrm{HO}_{x}, \mathrm{NO}_{x}$ and the $\mathrm{Hg}$ lifetime, Atmos. Chem. Phys., 8, 887-900, doi:10.5194/acp-8-887-2008, 2008.

Saiz-Lopez, A., Plane, J. M. C., Cuevas, C. A., Mahajan, A. S., Lamarque, J.-F., and Kinnison, D. E.: Nighttime atmospheric chemistry of iodine, Atmos. Chem. Phys., 16, 15593-15604, doi:10.5194/acp-16-15593-2016, 2016.

Sander, R., Rudich, Y., von Glasow, R., and Crutzen, P. J.: The role of $\mathrm{BrNO}_{3}$ in marine tropospheric chemistry: A model study, Geophys. Res. Lett., 26, 2857-2860, doi:10.1029/1999GL900478, 1999.

Savarino, J., Morin, S., Erbland, J., Grannec, F., Patey, M. D., Vicars, W., Alexander, B., and Achterberg, E. P.: Isotopic composition of atmospheric nitrate in a tropical marine boundary layer, P. Natl. Acad. Sci. USA, 110, 17668-17673, doi:10.1073/pnas.1216639110, 2013.

Scharko, N. K., Berke, A. E., and Raff, J. D.: Release of Nitrous Acid and Nitrogen Dioxide from Nitrate Photolysis in Acidic Aqueous Solutions, Environ. Sci. Technol., 48, 11991-12001, doi:10.1021/es503088x, 2014.

Sherwen, T., Evans, M. J., Carpenter, L. J., Andrews, S. J., Lidster, R. T., Dix, B., Koenig, T. K., Sinreich, R., Ortega, I., Volkamer, R., Saiz-Lopez, A., Prados-Roman, C., Mahajan, A. S., and Ordóñez, C.: Iodine's impact on tropospheric oxidants: a global model study in GEOS-Chem, Atmos. Chem. Phys., 16, 11611186, doi:10.5194/acp-16-1161-2016, 2016.

Simpson, W. R., Brown, S. S., Saiz-Lopez, A., Thornton, J. A., and Von Glasow, R.: Tropospheric Halogen Chemistry: Sources, Cycling, and Impacts, Chem. Rev., 115, 4035-4062, doi:10.1021/cr5006638, 2015.
Sommariva, R. and Von Glasow, R.: Multiphase halogen chemistry in the tropical atlantic ocean, Environ. Sci. Technol., 46, 1042910437, doi:10.1021/es300209f, 2012.

VandenBoer, T. C., Markovic, M. Z., Sanders, J. E., Ren, X., Pusede, S. E., Browne, E. C., Cohen, R. C., Zhang, L., Thomas, J., Brune, W. H., and Murphy, J. G.: Evidence for a nitrous acid (HONO) reservoir at the ground surface in Bakersfield, CA, during CalNex 2010, J. Geophys. Res.-Atmos., 119, 9093-9106, doi:10.1002/2013JD020971, 2014.

Vogt, R., Sander, R., Von Glasow, R., and Crutzen, P. J.: Iodine chemistry and its role in halogen activation and ozone loss in the marine boundary layer: A model study, J. Atmos. Chem., 32, 375-395, doi:10.1023/A:1006179901037, 1999.

Whalley, L. K., Furneaux, K. L., Goddard, A., Lee, J. D., Mahajan, A., Oetjen, H., Read, K. A., Kaaden, N., Carpenter, L. J., Lewis, A. C., Plane, J. M. C., Saltzman, E. S., Wiedensohler, A., and Heard, D. E.: The chemistry of $\mathrm{OH}$ and $\mathrm{HO} 2$ radicals in the boundary layer over the tropical Atlantic Ocean, Atmos. Chem. Phys., 10, 1555-1576, doi:10.5194/acp-10-1555-2010, 2010.

Wojtal, P., Halla, J. D., and McLaren, R.: Pseudo steady states of HONO measured in the nocturnal marine boundary layer: a conceptual model for HONO formation on aqueous surfaces, Atmos. Chem. Phys., 11, 3243-3261, doi:10.5194/acp-11-32432011, 2011.

Ye, C., Gao, H., Zhang, N., and Zhou, X.: Photolysis of Nitric Acid and Nitrate on Natural and Artificial Surfaces, Environ. Sci. Technol., 50, 3530-3536, doi:10.1021/acs.est.5b05032, 2016a.

Ye, C., Zhou, X., Pu, D., Stutz, J., Festa, J., Spolaor, M., Tsai, C., Cantrell, C., Mauldin, R. L., Campos, T., Weinheimer, A., Hornbrook, R. S., Apel, E. C., Guenther, A., Kaser, L., Yuan, B., Karl, T., Haggerty, J., Hall, S., Ullmann, K., Smith, J. N., Ortega, J., and Knote, C.: Rapid cycling of reactive nitrogen in the marine boundary layer, Nature, 532, 489-491, doi:10.1038/nature17195, 2016b.

Zhou, X., Civerolo, K., Dai, H., Huang, G., Schwab, J., and Demerjian, K.: Summertime nitrous acid chemistry in the atmospheric boundary layer at a rural site in New York State, J. Geophys. Res. Atmos., 107, ACH 13-1-ACH 13-11, doi:10.1029/2001JD001539, 2002.

Zhou, X., Gao, H., He, Y., Huang, G., Bertman, S., Civerolo, K., and Schwab, J.: Nitric acid photolysis on surfaces in low-NO $\mathrm{N}_{x}$ environments: significant atmospheric implications, Geophys. Res. Lett., 30, ASC 12/1-ASC 12/4, doi:10.1029/2003GL018620, 2003. 